\title{
Attitudes and Perceptions of Saudi EFL Teachers in Implementing Kingdom of Saudi Arabia's Vision 2030
}

\author{
Nurah Oddah Ahmad Al-Zahrani (Corresponding author) \\ Ministry of Education \\ P. O. Box 80200, Jeddah, 21589 \\ E-mail: teacher.nura.efl@gmail.com \\ Hussam Rajab \\ English Language Institute \\ King Abdulaziz University \\ Jeddah, Saudi Arabia
}

Tel: 966-559-802-922Ｅ-mail: hmrajab@kau.edu.sa

Received: January 31, 2017 Accepted: February 12, 2017 Published: February 14, 2017

doi:10.5296/ijele.v5i1.10733 URL: http://dx.doi.org/10.5296/ijele.v5i1.10733

\begin{abstract}
The study aimed at exploring the attitudes and perceptions of English as a Foreign Language (EFL) teachers at public schools in the Kingdom of Saudi Arabia, in achieving the Kingdom's '2030 Vision' which relates to the development of education in general and to the EFL discipline in particular. The study adopted the descriptive approach by utilizing a survey tool for the study which consisted of nineteen items divided into four constructs. The study sample consisted of 550 female and 450 male, Saudi government schools EFL teachers from the main regions of the Kingdom. The results of the statistical analysis of the responses of the participants indicated overwhelmingly a high level of positive attitude towards professional development in the teaching of English Language (EL), reaching 91\% as well as a near unanimity in the responses of the participants which was reflected in the lack of statistically significant relationship between the responses of the participants towards implementing 2030 vision through the achievement of professional development as well as working towards establishing international networking with teachers of English in various countries around the
\end{abstract}




\section{Macrothink}

International Journal of English Language Education

ISSN 2325-0887 2017, Vol. 5, No. 1

world. The results also indicated that there are still certain obstacles that may adversely affect the implementation of the vision of Saudi Arabia in 2030. Thus, the researchers have made several recommendations including conducting future research studies that will look into further areas not covered by this study.

Keywords: Vision 2030, Saudi Arabia - English as a Foreign Language (EFL) education professional development - public schools 


\section{Introduction}

The wisdom of Almighty God in our existence is manifested in creating us diverse as nations, tribes and races to meet and know each other. Among the factors which may lead to the success of this acquaintanceship between tribes, peoples and nations of the world is the successful and effective communication which leads to good welfare, prevalence of peace and cultural exchange between different nations of the world. Learning foreign languages, especially English language, is necessary for the success of this communication. English is nowadays undoubtedly, the common language for communication between different countries, peoples, races and ethnicities around the world. Thus, many elements leading to the prosperity of countries around the world rely on such good communications. The Kingdom of Saudi Arabia recognizes such arena and when His Royal Highness (HRH) Prince Mohammed bin Salman bin Abdul Aziz, the deputy Crown Prince of the Kingdom of Saudi Arabia, launched the initiative of "Saudi vision of 2030", it included in its content several points; among the most important of which, is the kingdom's vision for establishing a distinguished education that stems from the joint cooperation between government and business establishments to overcome the difficulties faced in international communications with the Kingdom. Additionally, it aims at searching for common grounds of cooperation between Saudi Arabia and other countries around the world in various fields (economic, educational, medical..etc.) in general, and the achievement of a comprehensive advancement and improvement of education and training environment at Saudi government schools and universities in particular which includes the development of English language teaching and overcoming the obstacles that still stand as a stumbling block in achieving these goals. In order to achieve that success in the development of teaching English language to be in line with the Kingdom's vision of 2030, important steps must first be taken; the most important of which is the effective and continuous training of the various educational cadres for teaching English language. The need for academic processing and effective training are two central and fundamental elements for teachers in general and for English language teachers in particular, regardless of the fact that the English teachers are highly qualified or not. There must be a specific mechanism for the continuous professional development for these teachers and in order to raise teachers' efficiency levels inside the classrooms and to improve learning outcomes in line with vision of 2030. This is due to the fact that recent research studies have indicated that the overall evaluation for of the majority the most of English teachers in the Kingdom of Saudi Arabia does not reveal optimum levels which is reflected in the performance of a large proportion of intermediate and secondary stage students which is considered very low (Alrabai, 2016; Saidi, 2009).

\subsection{The Study Problem and Research Questions}

Due to the fact that the two researchers work as EFL teachers; the first researcher works as an EFL teacher at a public high school for girls and the other, at a university in the Western region of Saudi Arabia and due to their extensive experience in teaching English language, they formed an overall picture about English language teaching, especially that which relates to newly graduating EFL teacher as they face difficulties in applying effective teaching and learning methods which ultimately does not reflect positively on the students' overall 
performance in English language learning. In order to find meaningful solutions and to improve the performance EFL teachers, the Ministry of Higher Education has applied multiple professional development methods such as in-service and after-service training programs in order to develop teaching practices for teachers inside classrooms. However, EFL teachers still face several obstacles that hinder their overall performances, effective preparation for lessons, teaching methodologies as well as the assessment methods which still reflect negatively on students' English language performance at Saudi government schools. In addition, most of English language teachers perceive that limited interaction, limited imagination, and limited diversity and creativity in their teaching, as the main obstacles. In light of what has been mentioned above, the researchers formulated an initial perception of the main aspects of this problem, and also felt that there is a lack in educational competence for EFL teachers. Furthermore, there is a need for a thorough understanding for developing the essence and the foundations of English language teaching to be consistent with the vision of 2030 in order to achieve high levels of education in general, and in learning English language in particular. Thus, the researchers determined that there is a need to conduct a research study in order to investigate the role of EFL teachers in achieving the vision of the Kingdom of Saudi Arabia in 2030, and to learn about the readiness of those teachers for instructions and methodologies that are currently used in teaching English to public school students in Saudi Arabia. In light of the above, the study problem can be stated in the following main research question:

- What are the perceptions and attitudes of EFL teachers with regards to their role in achieving the Kingdom of Saudi Arabia's vision of 2030 as well as their efforts in raising students ' performance at Saudi public schools?

Furthermore, the researchers formulated several sub questions that branch out from the main research question above. These sub questions are:

1. How committed are the English language teachers about their involvement in various professional development fields in relation to teaching English at Saudi government schools?

2. What are the views of EFL teachers at Saudi public schools on the English language level and its performance of students in general?

3. What are the successful methods that should be activated and practiced in teaching English as per the views of EFL teachers at public schools in line with achieving the Saudi vision of 2030 ?

4. What is the level of readiness of English language teachers at Saudi public schools to overcome obstacles and to implement any positive changes which may occur in the future and their interaction with them in order to promote the level of English language teaching at Saudi government schools?

5. What are the professional opportunities that EFL teachers perceive to have an 
effective impact on developing their professional performance which may lead to positive changes in the achievements of Saudi public school students and which will be reflected positively in achieving Vision of 2030?

\subsection{The Objectives of the Study}

The present study aimed at identifying the extent of the readiness of EFL teachers at Saudi government schools in interacting with the requirements of the significant changes that will lead to the development of their performance in teaching English language in line with achieving the 2030 vision. The study also aimed at identifying obstacles and causes of failure in EFL teachers' performance, which may reflect negatively on students' results at Saudi government schools, in addition to identifying the views of English language teachers at public schools regarding the following:

1. Saudi English language teachers' knowledge of the educational aspect of the 2030 vision in general and the aspect of teaching English in particular.

2. Identification of the EFL teachers' views regarding the obstacles they face in teaching English language.

3. Recognition of Saudi EFL teachers' participation in local and international educational conferences and seminars.

4. Recognizing the willingness of EFL teachers at Saudi government schools to communicate with EFL in other countries.

5. Identifying the motivation level of Saudi EFL teachers to develop their performance on an ongoing basis.

\subsection{Significance of the Study}

The Significance of study can be summarized in the following points:

1. Identifying the reasons which hinder the performance of EFL teachers that may reflect negatively on the students' achievement in English.

2. Identifying obstacles that Saudi English language teachers perceive as hindering their performance development in teaching English.

3. Identifying the hopes and aspirations of Saudi EFL teachers at government schools and stating these inspirations in an academic study that may help in achieving the 2030 vision with respect to teaching English.

4. Identifying areas related to developing the performance of EFL teachers in Saudi Arabia in order to achieve the 2030 vision and defining these areas for the academic community in the Kingdom of Saudi Arabia. 


\subsection{Delimitations of the Study}

There are several delimitations of this study, namely:

1. This study is limited to the attitudes and perceptions of EFL teachers at Saudi public schools only in achieving the 2030 vision.

2. This study is also limited to Saudi public school EFL teachers only and not in other countries.

3. This study was conducted during the span of one academic semester.

4. This study is also limited by the research design, instruments, and statistical methods used. Therefore, the possibility of generalizing the results of this study is linked to its previously mentioned delimitations.

\section{Literature Review}

English is a prominent language worldwide. It has become the lingua franca of the world since it is the main language by which people of different cultures and languages can communicate with each other. Thus, it is the common factor in communication between different countries of the world (Al Mukhallafi, 2014). It is one of the main and compulsory subjects, of the government school curriculum, which is taught at Saudi government schools starting from the fourth grade until graduation from high school at the age of 18 (Mahboob \& Elyas, 2014). Most of Saudi universities, if not all, requires an admission (proficiency) test to be taken by the new students. The passing of the test at a certain level needs to be attained before allowing the student to begin a study in an academic specialization (undergraduate course). For these reasons, the Saudi ministry of Education paid a great attention to English language because of its significance in various academic studies (ur Rahman \& Alhaisoni, 2013). English is one of the key factors in the success and continuity of the international economic relations. Furthermore, English is an essential element to build political, cultural and other relations with other countries around the world. While these efforts by the Saudi ministry of higher education are undoubtedly evident, there are still many obstacles that face students at Saudi government schools, which may be ascribed to many factors; the most important of which is the lack of motivation among the students to learn English (Mohammed, 2016; Rajab \& Al-Sadi, 2015). Alrabai (2016) fully discussed the issue of learning English language in Saudi Arabia. He stated that: " In English language classes in Saudi Arabia, teachers are considered authoritative characters who dominate the learning process; they adopt the role of presenters of knowledge rather facilitators of learning (Alrabai, 2014). Consequently, learners in this context rely on their teachers as the main source of knowledge (Alkubaidi, 2014) and are typically considered passive observers" (p. 24). In addition, English language learning level is generally rated as low at Saudi public schools (BinObaid, 2016; Springsteen, 2014; Wiseman, Sadaawi, \& Alromi, 2008). Altwaijri (1982) stated that "Saudi students study English for nearly ten years, yet their overall performance level in English is low" (p. 6). For the above-mentioned reasons, the majority of students, who move from high school to university, generally lack the skills and motivation in learning and in 
acquiring English language, and that lack is evidenced by their low scores (Al-Nasser, 2015; Alrahaili, 2013; Alrashidi \& Phan, 2015; Elyas \& Picard, 2010). Thus, it was necessary to take initiatives and to conduct comprehensive academic projects for searching for the best ways and means to improve the quality of teaching and learning English at Saudi government schools.

\subsection{Kingdom's 2030 Vision}

The declining dependency of countries around the world on oil led Saudi Arabia to undertake a transformation into the kingdom's oil-dependent economy. The Saudi government has planned several measures to restructure the country's economy and in light of such efforts, HRH Prince Mohammed bin Salman announced Vision 2030. He led the biggest economic shakeup since the founding of Saudi Arabia in 1932 (Yusuf, 2016). With the launching of the 2030 Vision by the deputy Crown Prince Mohammed bin Salman bin Abdul Aziz, there will be a restructuring for Saudi curriculum according to this vision for the future (Al-Maimooni, 2016). Due to the fact that this study is relatively a recent study compared to the announcement of the 2030 vision, there is still a lack of prominent research studies in that area. To the best of the knowledge of the researchers, there are not any in - depth research studies on the role of EFL teachers in Saudi Arabia in achieving the 2030 vision. However, there may have been some ideas and proposals that have been presented at conferences and academic forums; the most important of which was the first international Conference on Teaching English language, which was held under the auspices of Jeddah University, between Monday, $31^{\text {st }}$ of October and Wednesday, the $2^{\text {nd }}$ of November 2016, where many speakers and international experts in the field of developing English language teaching discussed issues relating to the improvement of the level of English language learning in line with the 2030 vision. The Dean of English language Institute and the conference chairman, Dr. Saeed Aburzaizah has expressed this orientation, stating that the goal of the conference was to combine cultures and experiences as well as reflecting the vision of the Kingdom in 2030 by transforming the challenges of education into investment opportunities so as to achieve the national transformation such as establishing centers for teaching the English language, designing and implementing special diplomas aiming to raise the quality of performance, adopting the national standards for the teaching profession and ensuring educational opportunities for all society segments in order to ensure a quality leap in English language skills levels (Al-Sulami, 2016). Furthermore, Dr. Tahany Al-Baiz, an associate professor of EFL Curriculum \& Instruction at the University of Jeddah, stated that " the educational needs for the students and the current and futuristic economic conditions require an insight for the future and exploration for the most important personal, professional and academic skills for language learners as the purpose of learning the language twenty years ago, is different from that purpose today. As a result, a new philosophy emerges to build curriculum and to select the scientific content and its associated contexts" She further states that: "it is now necessary to prepare the student to master the language not only as a crossing channel from one level to the next but also to engage him in the academic field and the labor market" (Al-Sulami, 2016). This conference was an important arena, not only in relation to vision the Kingdom in 2030 in general, but also in relation English language teaching in particular. Dr. Saeed 
Aburzaizah indicated the impact of the conference where he hopes to: "see a range of opportunities that attract investment in the educational sector and that improve education and training environment in general and teaching English in particular" (Reports, 2016b). In the same respect, Dr. Mohammed Obaid Al-She'hhi, a specialist in the Department of Curriculum at Imam Muhammad bin Saud Islamic University in Riyadh city, stated that there should be: "a means of permanent communication, and open channels in order to improve and develop the use of English to cope with the 2030 vision.... English in Saudi Arabia is still a foreign language and not a second official language ..... students live a painful and difficult reality with the English language........the kingdom has spent billions of Riyals on the developing English language curriculum since the days of the late King Abdullah, yet the problem still exists. Thus, the ministry of education represented by universities, schools, and educational institutions must intensify their efforts to improve and develop the use of English to cope with the 2030 vision" (Reports, 2016a). Mr. Samer Abdul Karim Fattani, a researcher in English language teaching affairs, stated that in order to address EFL teaching in Saudi Arabia, several areas must be addressed first; including the issue of modern academic dishonesty, some students commit, which must be addressed in an educational and social manner in order to achieve the vision of 2030 (Fatani, 2016). Mr. Fattani attributed the trend of parents to register their children at private or international schools to the advantageous and advanced learning of English for children since childhood so as to be at an advanced level once they reach the university admission stage. He further suggested addressing two major points to develop methods of teaching English in line with the 2030 vision, namely:

a) Source Crowding: participation through social networking platforms which are available on the internet to solve chronic and intractable teaching and learning problems.

b) Collaboration: cooperation and participation at school, college, and university level to achieve a common goal and to get out of professional isolation. (Burden, 2012).

\section{Methodology}

\subsection{Research Methodology and Statistical Treatment}

The Researchers used the investigative analytical approach in order to answer the questions of the study. Means and standard deviations were calculated to identify the attitudes and perceptions of EFL teachers in Saudi government schools in achieving the Saudi vision of 2030 of developing English language learning for Saudi public school students.

\subsection{Procedures of the Study}

\subsubsection{Research Sample}

The research sample consisted of the research community itself (all EFL teachers at Saudi public schools). The sample was randomly selected without any bias towards gender, age or area.

\subsubsection{Instrument of the Study}


1. The researchers prepared a checklist of the EFL teaching requirements at Saudi government schools in line with the 2030 vision by reviewing the literature and previous studies in the field.

2. Preparing and administering a questionnaire (piloting) to an experimental group which was not included in the main research sample of this study in order to confirm the validity, reliability and readiness of the questionnaire to be sent for participants. In addition, the researchers divided the questionnaire to reflect on the answers needed to study questions.

3. Using Microsoft Excel and IBM SPSS for analyzing and processing the data.

\subsection{Results and Statistical Analyses}

\subsubsection{Validity, Reliability and Suitability of the Questionnaire}

The researchers ensured the validity of the questionnaire using two basic methods. First, face validity, the initial version of the questionnaire was presented to a group of highly qualified juries in the field of English language curriculum and instructions and educational psychology to give their comments on the content of the questionnaire, its organization, appropriateness of items, clarity, language, association of indicators with each result, and the appropriateness of the questionnaire content to the to the level of English language teachers in the Saudi government schools. Juries were asked to delete or add whatever necessary. In the light of the juries' comments and views, some vocabularies, expressions, and structures were modified for some items, also some results were moved from one level to another, some items were deleted because of repetition, and some alternatives were modified. The final form of the questionnaire was finalized and presented to a pilot group composed of 10 male teachers and 10 female teachers who were randomly chosen in order to verify the reliability of the questionnaire. The pilot sample completed the questionnaire without any hindrance or comments on the difficulty or the clarity of the questionnaire. The questionnaire was uploaded to surveymonkey.com and its link was https://www.research.net/r/NURA2030 . The questionnaire was electronically sent to the sample of the study which consisted of 550 female teachers and 450 male teachers. Results were saved in an SPSS file and statistical analyses for participants' performance were conducted. of members of the study. Cronbach 's alpha coefficient for internal consistency was calculated and found to be 0.81 which is an appropriate value for the purposes of this study (Dileo, 2014). (Table 1).

Table 1. Cronbach's alpha coefficient for internal consistency

\section{Reliability Statistics}

\begin{tabular}{|c|c|}
\hline Cronbach's Alpha & N of Items \\
\hline .81 & 18 \\
\hline
\end{tabular}


In addition, the validity of the questionnaire was ensured by calculating Pearson's correlation coefficient between the score of each item and the total score of the questionnaire. All correlation coefficients were positive, acceptable and statistically significant at 0.01 level. All correlation coefficients between attitudes and the total score were positive and ranged between 0.63 and 0.87 and thus, these correlation coefficients would be acceptable for the purposes of this study.

\subsubsection{Results}

Since this questionnaire adopted Likert five-point scale in its primary investigative component, each answer has coded as follows: strongly agree $=5$, agree $=4$, undecided (I don't know) $=3$, disagree $=2$, and Strongly disagree $=1$. In addition, "strongly agree" and "agree" options were integrated under the positive item. Also, "disagree" and "strongly disagree" were integrated under the negative item. So, the results obtained by the researchers were as follows:

First: Results related to the first question, "How serious is the English language teachers in involving in various professional development fields in relation to teaching English language in Saudi government schools?" To answer this question, means for teachers' responses in relation to professional development fields (items 11,12, and 19) were calculated. Table 2 shows these results:

Table 2 shows means of teachers' views regarding professional development fields

\begin{tabular}{|c|l|c|c|c|}
\hline No & \multicolumn{1}{|c|}{ Item } & $\begin{array}{c}\text { Mean } \\
\text { Positive }\end{array}$ & $\begin{array}{c}\text { Mean } \\
\text { undecided }\end{array}$ & $\begin{array}{c}\text { Mean } \\
\text { Negative }\end{array}$ \\
\hline 11 & $\begin{array}{l}\text { communication between English language } \\
\text { teachers around the world is a means of } \\
\text { professional development }\end{array}$ & $95 \%$ & $2 \%$ & $3 \%$ \\
\hline 12 & $\begin{array}{l}\text { English as a Foreign Language teachers in } \\
\text { Saudi Arabia have a lot of expertise and } \\
\text { experience to share with other teachers } \\
\text { around the world }\end{array}$ & $\begin{array}{l}\text { (3) } \\
\text { Exchanging views and continuous } \\
\text { communication between English language } \\
\text { teachers around the world leads to the } \\
\text { development of learning English in Saudi } \\
\text { Arabia }\end{array}$ & $3 \%$ & $4 \%$ \\
\hline
\end{tabular}

Table 2 illustrates a positive attitude among the participants of the questionnaire as the majority of them views communication with English language teachers around the word and sharing experiences and views as a positive indicator in achieving the Vision of 2030.

Second: Results related the second question: "What are English language teachers' views on the level of English in Saudi public schools? To answer this question, means for teachers' 
responses in relation to English language level (items 5, 6, 7, 17 and 18) were calculated.

Table 3 shows these results:

Table 3 shows Means for teachers' responses regarding English language level and performance

\begin{tabular}{|c|l|c|c|c|}
\hline No & \multicolumn{1}{|c|}{ Item } & $\begin{array}{c}\text { Mean } \\
\text { Positive }\end{array}$ & $\begin{array}{c}\text { Mean } \\
\text { undecided }\end{array}$ & $\begin{array}{c}\text { Mean } \\
\text { Negative }\end{array}$ \\
\hline 5 & $\begin{array}{l}\text { Teaching English language should start at an } \\
\text { earlier stage (first grade) compared to what it is } \\
\text { now }\end{array}$ & $71 \%$ & $7 \%$ & $22 \%$ \\
\hline 6 & $\begin{array}{l}\text { weekly hours of teaching English in public } \\
\text { schools are enough to comprehensively learn it. }\end{array}$ & $28 \%$ & $4 \%$ & $68 \%$ \\
\hline 7 & $\begin{array}{l}\text { Government curriculum related to learning } \\
\text { English language meet the students needs in } \\
\text { government schools }\end{array}$ & $53 \%$ & $12 \%$ & $10 \%$ \\
\hline 17 & $\begin{array}{l}\text { English is an unofficial foreign language and is } \\
\text { not a compulsory second language in Saudi } \\
\text { Arabia }\end{array}$ & $\begin{array}{l}\text { If you answered yes to the previous question } \\
\text { Question 17), is it necessary for English to a } \\
\text { second official language (not a foreign } \\
\text { language) in industry, education, medicine, } \\
\text { commerce if we are to achieve the goals of } \\
\text { Vision of 2030 in line with the achievement of } \\
\text { economic openness }\end{array}$ & $78 \%$ & $12 \%$ \\
\hline
\end{tabular}

Table 3 shows both positive and negative attitudes regarding participants' views about the level of teaching English language at Saudi government schools. This difference in views is ascribed to the nature of the questionnaire, as the majority of the participants believe that EFL teaching education should start at an earlier age. In addition, most of participants believe that English should be the second official language in the Kingdom of Saudi Arabia. On the other hand, regarding English weekly teaching hours, majority of teachers believe that weekly teaching hours of English language are not sufficient to the extent that leads to teaching English as required. Regarding curriculum, half of participants believe that curriculum satisfies the students' needs of learning English, while one third of participants believe that curriculum is not sufficient and does not satisfy the students' needs.

Third, Results related to the third question: "What are the successful methods that should be done and practiced in the teaching English in according to the views of English language teachers in public schools in line with achieving the vision of the Kingdom of Saudi Arabia in 2030?" To answer this question, means for teachers' responses in relation to English language level (items 5, 11, 13, 18 and 19) were calculated. Table 4 shows these results: 


\section{$\triangle 1$ Macrothink}

Table 4 shows Means for teachers' responses regarding the successful methods that should be done and practiced in the teaching English

\begin{tabular}{|c|c|c|c|c|}
\hline No & Item & $\begin{array}{c}\text { Mean } \\
\text { Positive }\end{array}$ & $\begin{array}{c}\text { Mean } \\
\text { undecided }\end{array}$ & $\begin{array}{c}\text { Mean } \\
\text { Negative }\end{array}$ \\
\hline 5 & $\begin{array}{l}\text { Teaching English language should start at an } \\
\text { earlier stage (first grade) compared to what it is } \\
\text { now }\end{array}$ & $73 \%$ & $5 \%$ & $22 \%$ \\
\hline 11 & $\begin{array}{l}\text { communication between English language } \\
\text { teachers around the world is a means of } \\
\text { professional development }\end{array}$ & $95 \%$ & $2 \%$ & $3 \%$ \\
\hline 13 & $\begin{array}{l}\text { Have you ever given the opportunity to see } \\
\text { English language textbooks and curricula in } \\
\text { other countries (Not in Saudi Arabia)? }\end{array}$ & $35 \%$ & $0 \%$ & $65 \%$ \\
\hline 18 & $\begin{array}{l}\text { If you answered yes to the previous question } \\
\text { (Question 17), is it necessary for English to a } \\
\text { second official language (not a foreign } \\
\text { language) in industry, education, medicine, } \\
\text { commerce if we are to achieve the goals of } \\
\text { Vision of } 2030 \text { in line with the achievement of } \\
\text { economic openness }\end{array}$ & $78 \%$ & $12 \%$ & $10 \%$ \\
\hline 19 & $\begin{array}{l}\text { Exchanging views and continuous } \\
\text { communication between English language } \\
\text { teachers around the world leads to the } \\
\text { development of learning English in Saudi } \\
\text { Arabia }\end{array}$ & $93 \%$ & $3 \%$ & $4 \%$ \\
\hline
\end{tabular}

Table 4 shows positive attitudes with respect to the four points associated with the successful methods that lead to improve the English language teaching level in public schools in Saudi Arabia. Most of respondents believed that reasons for improving English language teaching level include; starting teaching English language at an earlier stage, making English the second official language in Saudi Arabia, and communicating between English language teachers around the world. It is noticeable that the majority of participants (almost two thirds) did not have the opportunity to read English language textbooks or curricula in other countries around the world.

Fourth, Results related to the fourth question " What is the degree of readiness of English language teachers in public schools in Saudi Arabia to overcome the obstacles of any positive changes which may occur and interact with them in order to promote the English language teaching level in government schools in Saudi Arabia? " To answer this question, means for teachers' responses in relation to English language level in Saudi public schools (items 8, 12, 13, 14 and 19) were calculated. Table 5 shows these results: 


\section{Ml Macrothink}

International Journal of English Language Education

ISSN 2325-0887

2017, Vol. 5, No. 1

Table 5 Means for teachers' responses regarding overcoming obstacles that may arise and their interaction with the changes in order to promote the level of teaching English language in Saudi government schools.

\begin{tabular}{|c|c|c|c|c|}
\hline No & Item & $\begin{array}{c}\text { Mean } \\
\text { Positive }\end{array}$ & $\begin{array}{c}\text { Mean } \\
\text { undecided }\end{array}$ & $\begin{array}{c}\text { Mean } \\
\text { Negative }\end{array}$ \\
\hline 8 & $\begin{array}{l}\text { Academic proficiency for newly appointed } \\
\text { English language teachers are enough to teach } \\
\text { English }\end{array}$ & $40 \%$ & $28 \%$ & $32 \%$ \\
\hline 12 & $\begin{array}{l}\text { English as a Foreign Language teachers in Saudi } \\
\text { Arabia have a lot of expertise and experience to } \\
\text { share with other teachers around the world }\end{array}$ & $53 \%$ & $31 \%$ & $16 \%$ \\
\hline 13 & $\begin{array}{l}\text { Have you ever given the opportunity to see } \\
\text { English language textbooks and curricula in other } \\
\text { countries (Not in Saudi Arabia)? }\end{array}$ & $35 \%$ & $0 \%$ & $65 \%$ \\
\hline 14 & $\begin{array}{l}\text { If you have never read English language } \\
\text { textbooks books and curricula or communicated } \\
\text { with teacher in other countries, do you intend to } \\
\text { do so? }\end{array}$ & $85 \%$ & $0 \%$ & $15 \%$ \\
\hline 19 & $\begin{array}{l}\text { Exchanging views and continuous communication } \\
\text { between English language teachers around the } \\
\text { world leads to the development of learning } \\
\text { English in Saudi Arabia }\end{array}$ & $93 \%$ & $3 \%$ & $4 \%$ \\
\hline
\end{tabular}

Table 5 shows both positive and negative attitudes with respect to the five points associated with the readiness of English language teachers in Saudi public schools. Most of respondents believed that reasons for improving English language teaching level include; continuous communication with English language teachers around the world. In addition, the majority of participants expressed their intention to read English language textbooks or curricula in other countries around the world as almost two thirds of them did not get that opportunity. Regarding the academic competence for the newly appointed English language teachers, participants ' responses varied as $40 \%$ of believed that these competencies are present, $32 \%$ believed that these competencies are not present, while $28 \%$ were undecided. However, 53\% of the participants believed that English language teachers in the Saudi government schools have experiences that allow them to share with English teachers around the world, while $16 \%$ of respondents believed that these experiences are not existed, furthermore, $31 \%$ were undecided.

Fifth, Results of the fifth question "What are the opportunities that English language teachers view to have an effective and positive impact in developing their professional performance and which may lead to positive changes for public school students in Saudi Arabia and their achievement in English which will reflect positively on achieving the vision of 2030?" To answer this question, means for teachers' responses (items 11, 15, and 19) were calculated. 


\section{$\triangle$ Macrothink}

Table 6 shows these results:

Table 6 Means for teachers' responses regarding the opportunities that English language teachers view to have an effective and positive impact in developing their professional performance and which will reflect positively on achieving the vision of 2030

\begin{tabular}{|c|l|c|c|c|}
\hline No & \multicolumn{1}{|c|}{ Item } & $\begin{array}{c}\text { Mean } \\
\text { Positive }\end{array}$ & $\begin{array}{c}\text { Mean } \\
\text { undecided }\end{array}$ & $\begin{array}{c}\text { Mean } \\
\text { Negative }\end{array}$ \\
\hline 11 & $\begin{array}{l}\text { communication between English language } \\
\text { teachers around the world is a means of } \\
\text { professional development }\end{array}$ & $95 \%$ & $2 \%$ & $3 \%$ \\
\hline 19 & $\begin{array}{l}\text { Exchanging views and continuous } \\
\text { communication between English language } \\
\text { teachers around the world leads to the } \\
\text { development of learning English in Saudi } \\
\text { Arabia }\end{array}$ & $3 \%$ & $4 \%$ \\
\hline
\end{tabular}

\begin{tabular}{|c|c|c|c|c|c|c|c|c|}
\hline No & Item & $\begin{array}{c}\text { Mean } \\
\text { Twitter }\end{array}$ & $\begin{array}{c}\text { Mean } \\
\text { Facebook }\end{array}$ & $\begin{array}{c}\text { Mean } \\
\text { Instagram }\end{array}$ & $\begin{array}{c}\text { Mean } \\
\text { Skype }\end{array}$ & $\begin{array}{c}\text { Mean } \\
\text { WhatsApp/Line/Tango }\end{array}$ & $\begin{array}{c}\text { Mean } \\
\text { Email }\end{array}$ & $\begin{array}{c}\text { Mean } \\
\text { attending } \\
\text { Conferences }\end{array}$ \\
\hline $\begin{array}{c}\text { According to } \\
\text { your own } \\
\text { point of } \\
\text { view, what is } \\
\text { the most } \\
\text { appropriate } \\
\text { way to } \\
\text { communicate } \\
\text { with English } \\
\text { language } \\
\text { teachers } \\
\text { around the } \\
\text { world? }\end{array}$ & $7 \%$ & $2 \%$ & $8 \%$ & $4 \%$ & $10 \%$ & $4 \%$ & $65 \%$ \\
\hline
\end{tabular}

Table (6) shows positive attitudes regarding the three points which EFL teachers view to have an effective and positive impact in developing their professional performance and which may lead to positive changes for public school students in Saudi Arabia and their achievement in English which will reflect positively on achieving the vision of $2030.95 \%$ and $93 \%$ (respectively) stated that communication and exchanging views with English language teachers around the world cause advancement of English language teaching. Regarding the best ways to communicate with English language teachers around the world, nearly two thirds of respondents believed that attending conferences and forums is the best way to achieve this communication.

Sixth: t-test for the periods scale

Considering that the participants in this study were from both sexes, the researchers wanted 
to find out and investigate whether there were statistical differences between the views of both male and female teachers regarding specific points in the questionnaire. So the researchers conducted $\mathrm{t}$ - test according to the research design; two independent groups according to Alpha error value (type I error): $\alpha=.05$. Furthermore, the researchers conducted the $t$ - test using IBM SPSS Statistics 23® on items number 5, 6, 7, 8, 9, 10, 11, 12, 13, 14, 16, 17,18 and 19 of the questionnaire. All results showed that all values (P-value) for those items (comparing the views of male teachers to those of female teachers) were bigger than $\alpha=.05$. Therefore, we conclude that there were no statistically significant differences between the views of male teachers and those of female teachers regarding the aforementioned items in the questionnaire.

\section{Conclusions}

The aforementioned results and analyses showed that majority of participants, in this research, expressed their seriousness in developing their scientific and academic level to be in line with the Vision of 2030 for developing the educational process especially promoting English language teaching. This was observed by the views of the participants, which was submitted for each point in the questionnaire. It was noted that respondents' attitudes varied in some points, especially regarding if the newly appointed English language teachers are qualified to work in Saudi public school or not. $40 \%$ of participants believed that the newly appointed English language teachers are qualified to work in Saudi public school, 32\% believed they are not, while $28 \%$ were undecided. However, majority of the participants believed that communication and exchanging views between English language teachers around the world significantly develop their professional performance in teaching English language, and that the best way to do this is to attend conferences and forums that are interested in teaching English language. Hence it is clear that the English language teachers in Saudi public schools have a high level of academic awareness regarding developing English language teaching in line with the vision of the Kingdom of Saudi Arabia in 2030.

\section{Recommendations}

Based on what has previously been mentioned and concluded, the researchers recommends the following:

1. Enlarging the sample to include all regions of the Kingdom of Saudi Arabia in order to obtain greater results.

2. Conducting individual interviews with a random sample of English language teachers in Saudi government schools so as to get qualitative results and analyses to help the researcher getting a broader perspective for English language teachers in public schools in Saudi Arabia.

Adding different samples to include male and female students in public schools in Saudi Arabia as well as English language administrators and supervisors in order to carry out more comprehensive analyses and conclusions than what had been presented in this study. 


\section{Macrothink}

\section{References}

Al-Maimooni, M. (2016). A One Trillion Riyal Non-Oil Revenue Approaching: Deputy Crown Prince Reveals 13 National Initiatives for Kingdom's Futre Vision 2030, Journalist Article. Al-Yaum Newspaper. Retrieved from http://www.alyaum.com/article/4133366

Al-Nasser, A. S. (2015). Problems of English language acquisition in Saudi Arabia: An exploratory-cum-remedial study. Theory and Practice in Language Studies, 5(8), 1612.

Al-Sulami, A. (2016, 2nd November, 2016). The First International Conference of English Languages Concludes Its Sessions in Jeddah, Jounrnalist Article. Sabq Electronic Journal. Retrieved from https://goo.gl/bY8WMC

Al Mukhallafi, T. R. (2014). Computer assisted language learning for learning English in Saudi Arabia. Retrieved from http://trove.nla.gov.au/version/209106119

Alkubaidi, M. A. (2014). The relationship between Saudi English major university students' writing performance and their learning style and strategy use. English Language Teaching, 7(4), 83.

Alrabai, F. (2014). Motivational practices in English as a foreign language classes in Saudi Arabia: Teachers beliefs and learners perceptions. Arab World English Journal, 5(1), 224-246.

Alrabai, F. (2016). Factors underlying low achievement of Saudi EFL learners. International Journal of English Linguistics, 6(3), 21.

Alrahaili, M. R. M. (2013). Predictors of L2 attitudes and motivational intensity: a cross-sectional study in the Saudi EFL context.

Alrashidi, O., \& Phan, H. (2015). Education context and English teaching and learning in the Kingdom of Saudi Arabia: An overview. English Language Teaching, 8(5), 33. http://dx.doi.org/10.5539/elt.v8n5p33

Altwaijri, A. O. (1982). The Adequacy of Students' Preparation in English as a Foreign Language in the Saudi Schools: University of Oregon.

BinObaid, R. (2016). An Evaluation of the Second Intermediate Saudi English Language Textbook from the Teachers' Point of View. Advances in Language and Literary Studies, 7(2), 231-248.

Burden, K. (2012). Crossing the transformation horizon: Conceptualising teachers' learning and transformations with the affordances of Web 2.0. Doctoral dissertation, University of Hull). Retrieved from http://www2. hull. ac. uk/ifl/pdf/Burden, $\% 20 \mathrm{~K} \%$ 20Complete\% 20thesis. pdf.

Dileo, F. (2014). Criteria of Validity and Reliability in Quantitative and Qualitative Research Studies. Revue des Sciences Sociales, 19, 82-91.

Elyas, T., \& Picard, M. (2010). Saudi Arabian educational history: Impacts on English 


\section{Macrothink}

language teaching. Education, Business and Society: Contemporary Middle Eastern Issues, $3(2), 136-145$.

Fatani, S. A. (2016). Reflections: 10 Challenges to Address in order to Improve the Teaching of English Language in Education to Fulfill the 2030 Vision. Retrieved from http://samirportfolio1.blogspot.com/2016/05/10-2030.html

Mahboob, A., \& Elyas, T. (2014). English in the kingdom of Saudi Arabia. World Englishes, $33(1), 128-142$.

Mohammed, A. (2016). EFL effective factors: Anxiety and motivation and their effect on Saudi college student's achievement. Browser Download This Paper.

Rajab, H., \& Al-Sadi, A. (2015). An empirical study of reading habits and interests of Saudi university EFL learners. International Journal of Linguistics, 7(2), 1-16. http://dx.doi.org/10.5296/ijl.v7i2.7034

Reports. (2016a). An Academic Calls to Focus on Improving the Teaching of English Language so as not to Hinder the 2030 Vision. . Retrieved from Saudi Arabia: http://www.tmm24.org/146212

Reports. (2016b). Jeddah University Hosts the First International Conference of Teaching English [Press release]. Retrieved from http://ien.sa/node/5111

Saidi, A. (2009). Activating the Role of Educational Supervision in Training English Language Teachers. (Master's Dissertation), Umm Al-Qura University, Makkah, Saudi Arabia. Retrieved from http://libback.uqu.edu.sa/hipres/ABS/ind5928.pdf (IND5928)

Springsteen, S. M. (2014). Examining student motivation in Saudi Arabia.

ur Rahman, M. M., \& Alhaisoni, E. (2013). Teaching English in Saudi Arabia: prospects and challenges. Academic Research International, 4(1), 112.

Wiseman, A. W., Sadaawi, A., \& Alromi, N. H. (2008). Educational indicators and national development in Saudi Arabia.

Yusuf, N. A., Huda. (2016). Beyond Oil - The Transformation to a Market-Based Approach: Envision Saudi Arabia 2030. Journal of Economics and Sustainable Development, 7(14), 20 24.

\section{Copyright Disclaimer}

Copyright for this article is retained by the author(s), with first publication rights granted to the journal.

This is an open-access article distributed under the terms and conditions of the Creative Commons Attribution license (http://creativecommons.org/licenses/by/3.0/). 